\title{
Ethanol Fermentation of a Diluted Molasses Medium by Saccharomyces cerevisiae Immobilized on Chrysotile
}

\author{
Ranulfo Monte Alegre $^{1 *}$, Maurício Rigo ${ }^{1}$ and Inés Joekes ${ }^{2}$ \\ ${ }^{1}$ Faculdade de Engenharia de Alimentos; UNICAMP; C. P. 6121; 13083-970; Campinas - SP - Brazil. ${ }^{2}$ Instituto \\ de Química; UNICAMP; C. P. 6154; 13083-970; Campinas - SP - Brazil
}

\begin{abstract}
In this work, the catalytic role of chrysotile support on the acceleration of alcoholic fermentation under non-aseptic conditions by Saccharomyces cerevisiae was investigated. The fermentation medium employed consisted only of diluted sugar-cane molasses. In the batch fermentations process with immobilized yeasts, the initial rate of $\mathrm{CO}_{2}$ production increased roughly $27 \%$ during the first 30 minutes, compared to systems containing no chrysotile. A study of continuous alcoholic fermentation with chrysotile in the reactor bed showed a higher ethanol production rate at the different dilution rates investigated compared to similar fermentations without chrysotile.
\end{abstract}

Key words: Alcoholic continuous fermentations, alcoholic batch fermentations, immobilized yeast, chrysotile, ethanol

\section{INTRODUCTION}

There is a world wide search for alternative methods of energy production from renewable sources. Brazil is pioneer in large scale motor fuel ethanol production through the fermentation of sugar cane molasses by yeast (Sanches et al., 1996; Wheals et al., 1999). However, $30 \%$ of the industries have substituted batch by continuous fermentation processes (Wheals et al., 1999) because this presented several advantages. To improve the productivity and ethanol yield and to avoid the utilization of centrifuges that are expensive, continuous processes with immobilized cells in different carriers as glass, synthetic polymers as polyacrylamide (Lida, 1993) and polypropilene gels (Inloes et al., 1983), calcium alginate (Bravo and Gonzales, 1991; Gilson and Thomas, 1995; Roukas, 1994; Sanches et al., 1996), kissiris (Argiriou et al., 1996) have been suggested, although some carriers presented difficulties at industrial scale. For example, alginate beads that can be destroyed due to friction and $\mathrm{CO}_{2}$ evolution inside the beads (Gilson and Thomas, 1995).

Prakashan et al. (1999) investigated the catalytic role of various inert solids supports on acceleration of alcoholic fermentation by Saccharomyces cerevisiae. The tested supports were delignified sawdust, delignified wheat bran, river sand, chitin, chitosan and titanium oxide. The results of the alcoholic fermentation showed that all carriers stimulated ethanol production, which was attributed to the attachment of the cells to these materials. Bekers et al. (2000) used porous spheres stainless steel treated by oxidation with $\mathrm{TiCl}_{4}$ or aminopropyltrietoxilase, as carriers for yeast cells. They observed that the attachment of the cells on porous stainless steel treated was due to the electrostatic attraction between the cells that had

\footnotetext{
* Author for correspondence
} 
negative electric charges and the porous stainless steel treated that had positive charges. The assays of batch fermentation using an immobilized cells inoculum showed an increase of yeast cells stability and ethanol production. The authors suggest that increase of ethanol synthesis by cell immobilized in porous stainless treated could be the result of catalytic action of some carrier surface element on metabolism.

Chrysotile is a mineral of magnesium silicate present in nature in a fibrous form. It has an exceptional capability to immobilize yeast cells by adsorption, with some advantages when compared to the carriers cited in the literature, as it has excellent stability that allows its use for long periods and for reuse, shows resistance to thermal treatment, supports operational conditions of alcoholic fermentation, and is cheep (Moran et al., 1997), but the main advantage of this mineral is its stimulation of the ethanol production by yeast, increasing the specific productivity of the processes (Wendhausen et al., 2001; Filloy et al., 2001; Joekes et al., 1998).

The aim of this work was to investigate ethanol production by Saccharomyces cerevisiae cells supported on chrysotile, under non-aseptic conditions in continuous and batch fermentations, using diluted sugar-cane molasses as the source of carbon.

\section{MATERIALS AND METHODS}

\section{Microorganism and its maintenance}

The strain of Saccharomyces cerevisiae used in this work was isolated from an ethanolic fermentation of sugar cane molasses of Santa Délia sugar-ethanol industry - SP, Brazil, supplied by the Bioengineering Laboratory of the Food Department Engineering of the Universidade Estadual de Campinas - UNICAMP. S. cerevisiae was maintained at $4{ }^{\circ} \mathrm{C}$ on agar slants. The composition of the agar was $\left(\mathrm{g}^{-1}\right)$ : yeast extract 3 , malt extract 3 , peptone 5 , glucose 10 and agar 20 . The cultures were maintained by sub-culturing every 20-days and the test tubes were then incubated at $30{ }^{\circ} \mathrm{C}$ for $36 \mathrm{~h}$. The Baker's yeast, largely used in industrial process, was also used in this work. Commercial Baker's yeast was bought from Fleshmann and Royal Ltda (Brazil).

\section{Carrier}

Chrysotile $5 \mathrm{R}$ from SAMA S. A. Mineração de Amianto (Brazil) was used as the carrier, which was washed with tap water to remove sand particles and rock powder before its use.

\section{Fermentation medium}

The carbon source used was diluted sugar cane molasses with a sugar concentration of approximately $\quad 180 \quad \mathrm{~g} \quad \mathrm{l}^{-1} \quad$ without any supplementation. In the batch fermentation, the medium was not sterilized and the $\mathrm{pH}$ was adjusted to 4.5. In the continuous fermentation, the $\mathrm{pH}$ of the medium was adjusted to 5.5 and medium was sterilized at $120^{\circ} \mathrm{C}$ for 25 minutes.

\section{Inoculum preparation}

The inoculum was prepared aseptically in a twostage growth process. In the first stage, the microorganism was cultured in $250 \mathrm{ml}$ Erlenmeyer flasks containing $100 \mathrm{ml}$ of following medium $\left(\mathrm{g} \mathrm{l}^{-}\right.$ ${ }^{1}$ ): glucose 50 , yeast extract $5, \mathrm{KH}_{2} \mathrm{PO}_{4} 5, \mathrm{NH}_{4} \mathrm{Cl}$ $1.5, \mathrm{MgSO}_{4} 0.7$ and $\mathrm{KCl}$ 1.7. The Erlenmeyer flasks were incubated at $30{ }^{\circ} \mathrm{C}$ for 12 hours on a rotary shaker at $180 \mathrm{rpm}$. Afterwards the medium was transferred to a $4000 \mathrm{ml}$ Erlenmeyer flask containing $1000 \mathrm{ml}$ of the same medium, except the glucose was replaced by $150 \mathrm{~g} \mathrm{l}^{-1}$ of sucrose, and incubated under the conditions described above. The cells suspension obtained was vacuum filtered using Whatman paper number 1.

\section{Adsorption of the yeast cells on chrysotile and fermentation assays}

In batch fermentations, the cell mass was carefully added to each flask with molasses medium and chrysotile, to give the desired wet base yeast concentration. These fermentations were carried out in $250 \mathrm{ml}$ Erlenmeyer flasks with $100 \mathrm{ml}$ of medium on a rotary shaker at $200 \mathrm{rpm}$ and $30^{\circ} \mathrm{C}$. Erlenmeyer flasks were prepared containing free chrysotile in the medium or chrysotile in a sachet of organza textile of $4 \mathrm{~cm} \mathrm{x} 4 \mathrm{~cm}$, always up to $1 \%$ $(w / v)$ of the culture volume. Control Erlenmeyer flasks were prepared without chrysotile. Continuous fermentation was carried out in a 600 $\mathrm{ml}$ bench fermentor that was constructed using a Beaker of $620 \mathrm{ml}$ with a 1.1 height/diameter ratio, which was closed using a rubber cap, and had a tube inserted to recycle water at $30{ }^{\circ} \mathrm{C}$ from a thermostatic bath and another tube that reached the fermentor bottom for feeding. Mixing of the medium was promoted by a magnetic bar. Exit of 
the medium via a small tube in the fermentor body, and the samples were collected in a test tube submerged in a ice bath. The mass of chrysotile used in these fermentation was either 1 or $2 \%$ $(\mathrm{w} / \mathrm{v})$ of the culture volume and it was wrapped in three sachets of organza textile of $7 \mathrm{~cm} \times 8 \mathrm{~cm}$ regularly distributed in the bulk medium to avoid loss of that fibres from reactor bed through the exit tubing. At the beginning of fermentation, approximately $20 \mathrm{~g}$ wet weight of yeast cells were added to the nutrient medium contained in the reactor and maintained for two hours under agitation to leave the cells in contact with the chrysotile fibers to promote adsorption of the cells onto the chrysotile fibres. Then, the pulsation pump was turned on to feed the reactor at the desired dilution rate. A steady state was assumed when variations did not occur in the dry cellular mass and ethanol concentrations in three consecutives samples. The dilution rate was increased during the fermentation course until a rate of approximately $0.30 \mathrm{~h}^{-1}$ was reached. Karmoran antibiotic solution $\left(1 \mathrm{~g} \mathrm{l}^{-1}\right)$ was added in a range of 0.1 to $0.3 \mathrm{ml}$, in the reactor through the medium supplying tubing three times a day.

\section{Analysis}

The kinetics of batch fermentation was followed by determining $\mathrm{CO}_{2}$ mass evolution on the basis of the weight of the Erlenmeyer flasks as a function of time. Samples from continuous fermentation were centrifuged and the clarified supernatants were split in two aliquots. One of them was treated with an equal volume of HCL (2N) in boiling water bath for 15 minutes, followed by the addition of an equal volume of $\mathrm{NaOH}(2 \mathrm{~N})$. The reducing sugars were analysed by the SomogyNelson method (Somogyi, 1952). The other aliquot was distilled and the recovered ethanol was analysed using the method described by Salik and Povh, (1993).

\section{RESULTS AND DISCUSSION}

$\mathrm{CO}_{2}$ production by the batch ethanol fermentations are shown in the Figs. 1 and 2. Fig. 1 showed $\mathrm{CO}_{2}$ produced in the flasks containing wrapped and free chrysotile in relation to the control flasks, without wrapped and free chrysotile, which are represented by the ordinate zero. At the beginning of the fermentation, there was more $\mathrm{CO}_{2}$ production in the flasks with wrapped chrysotile than in those containing free chrysotile, but this difference decreased during the course of the fermentation and after 120, minutes there was no significant difference. Since the flasks with wrapped chrysotile in organza sachets produced more $\mathrm{CO}_{2}$ than the flasks with free chrysotile, experiments were carried out with the organza sachets without chrysotile in the fermentation medium to determine the influence of the sachets on the increase of the $\mathrm{CO}_{2}$. There was no difference in $\mathrm{CO}_{2}$ production in the control flasks and the flasks with organza sachet without chrysotile, which allowed to conclude that the acceleration of biological activity in the beginning of fermentation was due to the presence of chrysotile in the medium. Moreover higher evolution of $\mathrm{CO}_{2}$ in the flasks with wrapped chrysotile showed that the form in which chrysotile was present in the fermentation medium influenced the yeast activity. The changes in the productivity obtained for systems with immobilized cells on chrysotile could be explained by strong interaction between chrysotile and cells, which affected the structure of cells membrane (Joekes et al., 1998).

To confirm if the catalytic effect of chrysotile on the acceleration of alcoholic fermentation did not occur only the first time that it was used, the chrysotile used in the experiments of the Fig. 1 was reused again after being washed with distilled water sufficient times to remove all cells and medium impurities. The results are shown in Fig. 2 , which showed the same behavior observed in Fig. 1, despite the small differences in the initial cells and reducing sugar concentration. Such experiments showed that there was no factor or material present only in raw chrysotile when used for first time that could increase the fermentation rate, but on the contrary there was some evidence which showed that the increase of $\mathrm{CO}_{2}$ evolution was due the form of the cellular entrapment or due to some interaction of the cells and chrysotile. The rapid reduction of the chrysotile effect on the yeast activation in the first 60 minutes of fermentation suggested that the immobilized yeast was more susceptible to inhibition by ethanol formed in the fermentation than in the control or in conventional fermentation. A small difference of $\mathrm{CO}_{2}$ evolution rate in the flasks with wrapped or free chrysotile was observed in the Figs. 1 and 2, but there was a difference of the initial cellular concentration and total reducing sugars between both Fig.s that could justify the more rapid $\mathrm{CO}_{2}$ production (Fig. 2). 
Meanwhile, other experiments with initial yeast cells at concentrations in the range of 0.1 to $1 \%$ (wet weight) were carried out, but no difference of $\mathrm{CO}_{2}$ evolution rate in the flasks with chrysotile and the control flasks was observed (data not shown). Significant rates of $\mathrm{CO}_{2}$ evolution were observed only when the initial cellular concentration was up to $5 \%$ (wet weight).

In batch fermentation using Baker's yeast, with initial total reducing sugar concentration of $180 \mathrm{~g}$ $\mathrm{I}^{-1}$ and the initial cellular concentration of $8 \%$ in wet weight basis, no significant differences in the $\mathrm{CO}_{2}$ evolution were observed in the flasks containing $1 \%$ of wrapped and free chrysotile in relation to the control flasks, without wrapped and free chrysotile.

Fig. 3 shows the results of continuous fermentations, which were carried out to observe if the effect of wrapped chrysotile in sachets on the increase of the alcoholic fermentation rate during 12 days, in relation to the continuous control fermentation, without chrysotile. All experiments started with the lowest dilution rate that was gradually increased to reach the highest rate, and the ethanol productivity increased when the dilution rate increased. This behavior confirmed the observation of the fermentation carried out in
Erlenmeyer flasks that the catalytic effect on alcoholic fermentations was pronounced when the ethanol concentration in the medium was low, which occurred at dilution high rates. In the experiments carried out with $1 \%$ of reused wrapped chrysotile, ethanol productivity was lower than in experiments carried out with $1 \%$ of freshly wrapped chrysotile. This behavior was unexpected since in the batch fermentation no decrease in $\mathrm{CO}_{2}$ evolution rate was observed, despite the fact that all continuous fermentations were carried out several days with dilution rates lower that $0.20 \mathrm{~h}^{-1}$. Thus, the reduced catalytic effect of the reused chrysotile on alcoholic fermentation could not be attributed to the impurities in the molasses that could leave reduced or inhibited the adsorption of yeast cells to chrysotile fibers. On the other hand, the productivity values of the experiments with $2 \%$ of chrysotile were lower than the productivity values of the experiments with $1 \%$ of new chrysotile, which was not expected. These results suggested that the catalytic effect of the chrysotile should be further examined.

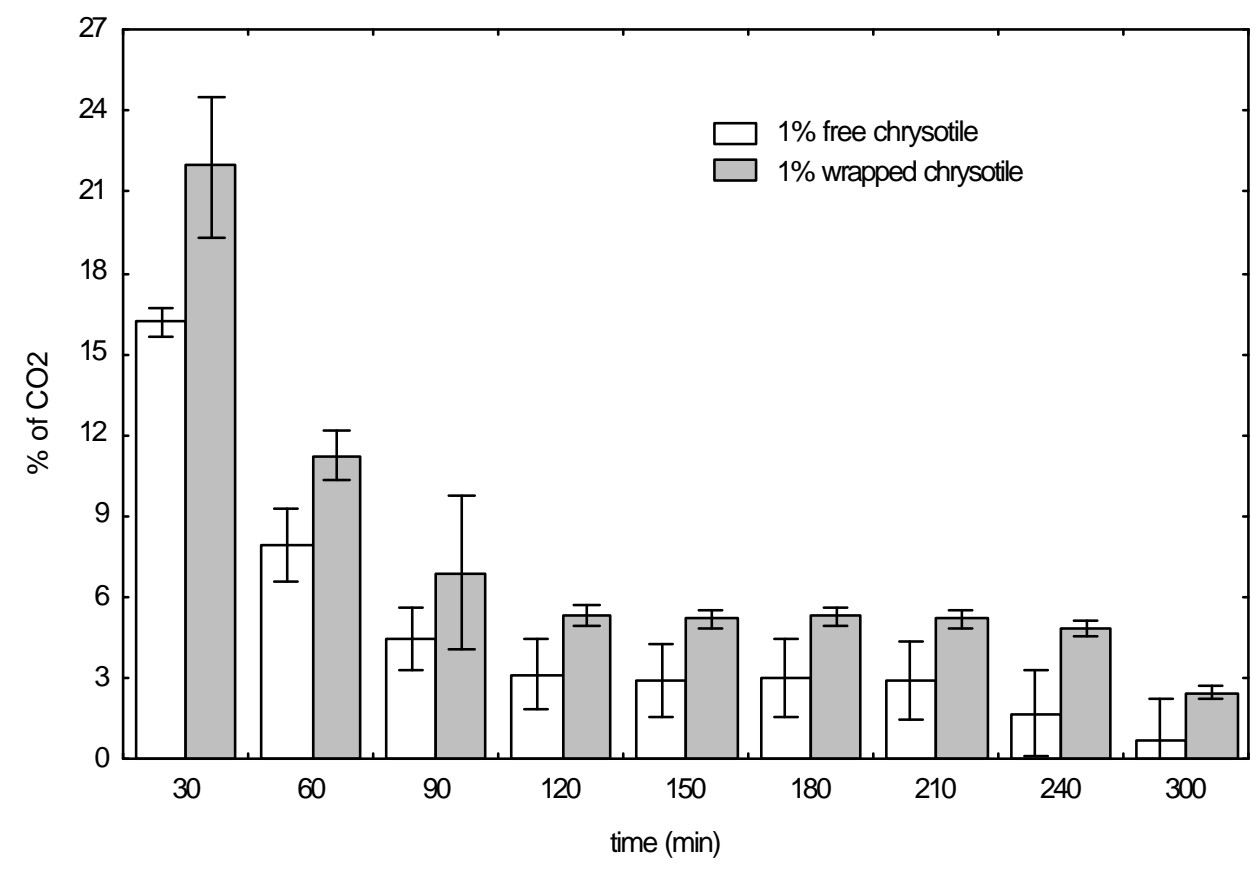

Figure 1 - Values of $\mathrm{CO}_{2}$ produced in the flasks with wrapped or free chrysotile compared to the $\mathrm{CO}_{2}$ produced in the control flasks, without chrysotile, in batch fermentation. The initial total reducing sugar concentration was of $179 \mathrm{~g}^{-1}$ and the initial cellular concentration $7.6 \%$ in wet weight basis. Triplicate average. The bars represented the standard error. 


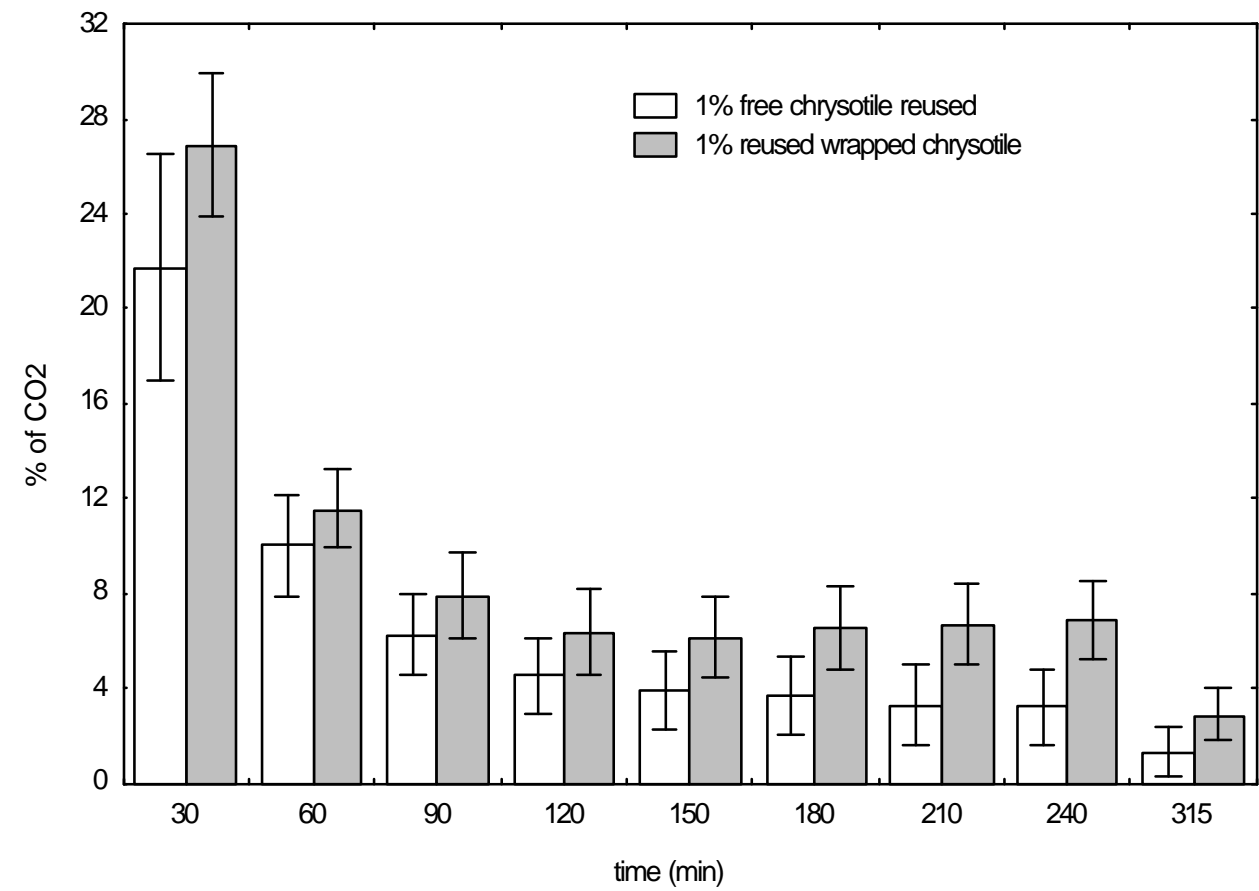

Figure 2 - Values of $\mathrm{CO}_{2}$ produced in the flasks with reused wrapped or free chrysotile compared to the $\mathrm{CO}_{2}$ produced in the control flasks without chrysotile, in batch fermentation. The initial total reducing sugars concentration was of $193 \mathrm{~g} \mathrm{l}^{-1}$, initial cellular concentration of $9.9 \%$ in wet weight basis. Triplicate average. The bars represented the standard error.

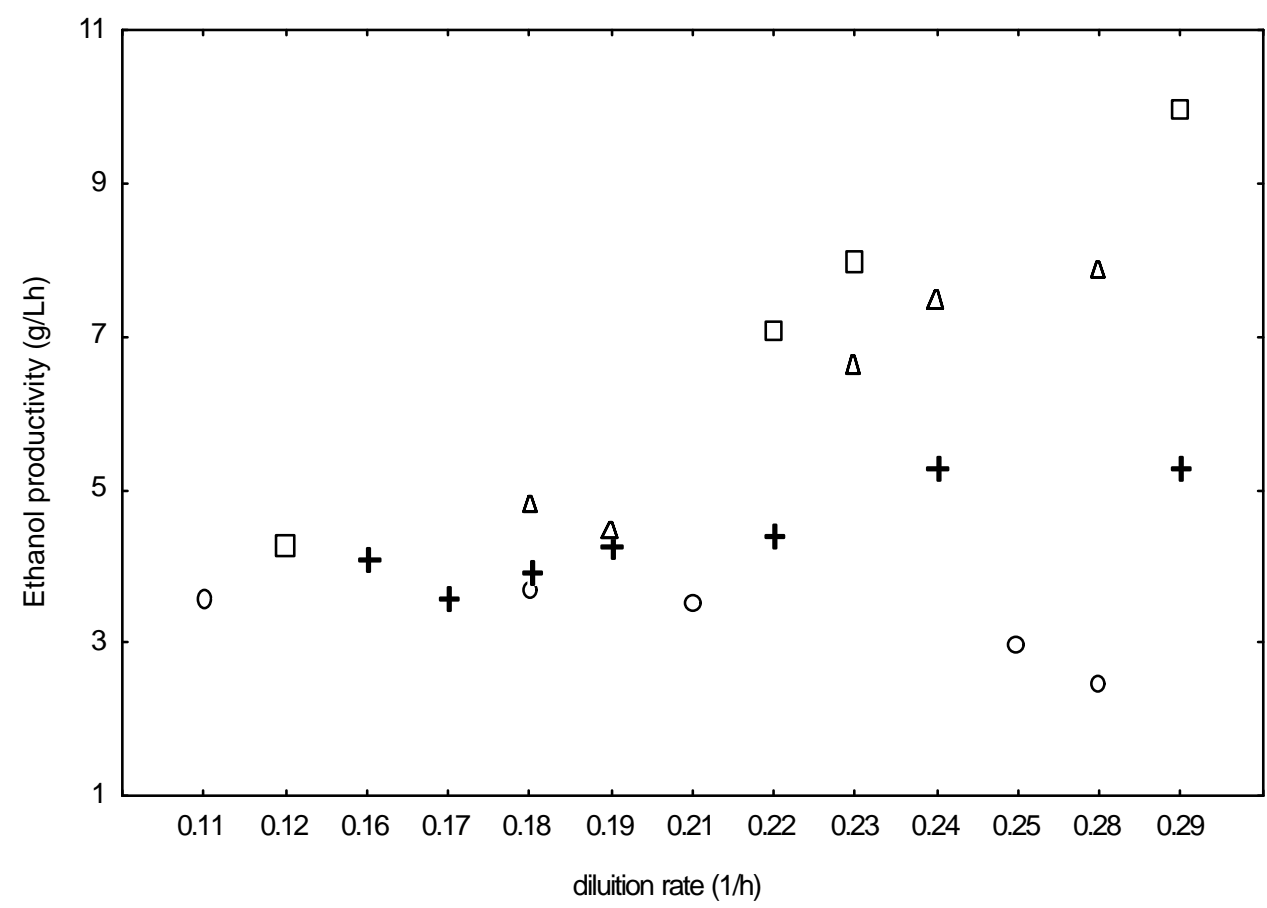

Figure 3 - Productivity values of the continuous alcoholic fermentations without any chrysotile (O), with $1 \%$ of wrapped chrysotile $(\square), 1 \%$ of reused wrapped chrysotile $(+)$ and $2 \%$ of wrapped chrysotile $(\Delta)$. 


\section{CONCLUSIONS}

The strain of $S$. cerevisiae used in this work was a good alcohol producer isolated from alcoholic industrial fermentation. Other strain of $S$. cerevisiae employed in bread industry was used but the chrysotile effect was not so pronounced with this strain. This fact suggested that the interaction between each strain and chrysotile was different and care should be taken in strain selection prior to use of chrysotile in alcoholic fermentations. Despite the positive effect on the reaction rate in the presence of chrysotile, it occurred only at the beginning of the fermentation and when a high yeast concentration was utilized. Its industrial use can be advantageous in batch or continuous fermentation, which is the case in Brazil where $30 \%$ of the industries that produce fuel alcohol use a continuous process in 3 or 4 fermentors connected in series. In both processes, the medium is centrifuged and the yeast obtained is treated with sulphuric acid $(\mathrm{pH} 2.0)$, then recycled to the batch or to the first stage fermentor to give a first stage fermentation with $10 \%$ of wet yeast cream, which is a good condition to use chrysotile.

In this work the experimental conditions were similar to those of a sugar cane fermentation industry, including the yeast number that was maintained at $10^{8}$ cells $/ \mathrm{mL}$ and contaminant (bacteria) that was maintained at $10^{6}$ cells $/ \mathrm{mL}$ by the antibiotic addition. Thus, fermentation with immobilized yeast cells on chrysotile could be suitable for scaling up.

The effect of chrysotile on bacteria or other fungi is unknown, but its application in other fermentation processes may be advantageous, if a similar effect as on the yeast alcoholic fermentation occurs, specially in those processes in which, unlike alcoholic fermentation, the products do not cause intense inhibition of the microbial activities.

\section{RESUMO}

Crisotila é um mineral constituído de silicato de magnésio de hábito fibroso abundante no Brasil e pode ser usada como suporte mineral para células de levedura em fermentação alcoólica com células imobilizadas. Neste trabalho foi investigada a função catalítica da presença de crisotila em fermentações alcoólicas com células de Saccharomyces cerevisiae sob condições não assépticas. O meio nutriente empregado foi melaço de cana-de-açúcar diluído. O suporte foi embalado em sachês de organza e distribuído dentro do reator, o qual durante as fermentações contínuas reteve as fibras de crisotila com células imobilizadas dentro do reator, aumentando sua densidade celular e evitando problemas de instabilidade operacional do mesmo. As fermentações alcoólicas em bateladas conduzidas com leveduras imobilizadas sobre o suporte apresentaram aumento de até $27 \%$ na velocidade inicial de conversão de açúcares a etanol mais $\mathrm{CO}_{2}$, em relação ao sistema controle sem presença de crisotila. Já nas fermentações contínuas com presença de crisotila em seu leito ocorreu aumento da produção de etanol nas diversas taxas de diluições investigadas, em relação a uma fermentação contínua sem crisotila, tomada como padrão. Esse aumento foi mais acentuado quanto maior a taxa de diluição.

\section{REFERENCES}

Argiriou, T. M.; Kanellakim, S.; Voliotis, A. and Koutinas, A. (1996), Kissiris-supported yeast cells: high biocatalytic stability and productivity improvement by successive preservations at ${ }^{\circ} 0 \mathrm{C}$. J. Agric. Food. Chem., 44, 4028-4031.

Bekers, M. E.; Ventina, A.; Karsakevich, I.; Vina, A.; Rapoport, D.; Upite, E.; Kaminiska, R. and Linde, R. (2000), Attachment of yeast to modified stainless steel wire spheres, growth of cells and ethanol production. Process. Biochem., 35, 523-530.

Bravo, P. and Gonzalez, G. (1991), Continuous ethanol fermentation by immobilized yeast cells in a fluidized bed reactor. J. Chem. Technol. and Biotechnol., 52, 127-134.

Filloy, P. H.; Fregonesi, A. and Joekes, I. (2001). Activation of Brazilian chrysotile surface using gas flow in batch reactors. Paper presented at Congress Proceedings of the International Conference on Advanced Materials Processing Technologies (AMPT 01) Volume 3. 18 - 21 of September Universidad Carlos III de Madri, Leganis, Spain.

Gilson, C. D. and Thomas, A. (1995), Ethanol production by alginate immobilized yeast in a fluidized bed bioreactor. J. Chem. Technol. Biotechnol., 62, 38-45. 
Inloes, D. S.; Taylor, D. P.; Cohen, S.N.; Michaels, A. S. and Roberson, C. R. (1983), Ethanol production by Saccharomyces cerevisiae immobilized in hollowfiber membrane bioreactors. Appl. Environ. Microbiol., 46, 264-278.

Joekes, I.; Moran, P. J. S.; Rodrigues, J. A. R.; Wendhausen, R. J. R.; Tonella, E. and Cassiola, F. (1998), Characterization of Saccharomyces cerevisiae immobilized onto chrysotile for ethanol production. J. Chem. Technol. Biotechnol., 73, 54-58.

Lida, T. (1993), Fuel Ethanol Production by Immobilized Yeast and Teast Immobilization. Bioprocess Technology: In: Industrial Application of Immobilized Biocatalysts. New York : Ed. Marcel Dekker. pp. 163-183.

Moran, P. J. S.; Wendhausen, R.; Rodrigues, J. A. R. and Joekes, I. (1997). Process of production of ethanol with high yield in continuous and batch fermentation using cells of Saccharomyces cerevisiae supported in minerals. Patente BR. 9.700.635.

Prakasham, R. S.; Kuriakose, B. and Ramakrishna, S. V. (1999). The influence of inert solids on ethanol production by Saccharomyces cerevisiae. Appl. Biochem. Biotechnol., 82, 127-134.

Roukas T. (1994), Continuous ethanol productions from carob pod extract by immobilized Saccharomyces cerevisiae in a packed bed reactor. J Chem Technol Biotecnhol., 59, 387-393.

Salik, F. L. M. and Povh, P. N. (1993), Método espectrofotométrico para determinação de teores alcoólicos em misturas hidroalcoólicas. Processamento, Engenharia Industrial $e$ Derivados, 262-266.

Sanches, E. N.; Alhadeff, E. M.; Rocha-Leão, M. H. M. and Pereira Jr., N. (1996), Performance of a continuous bioreactor with immobilized yeast cells in the ethanol fermentation of molasses-stillage medium. Biotechnol. Lett., 18, 91-94.

Somogyi, M. (1952), Notes on sugar determination. $J$. Biolog. Chem., 195, 19.

Wheals, A. E.; Basso, L. C.; Alvesand, D. M. G. and Amorim, H. V. (1999), Fuel ethanol after 25 years. Trends in Biotechnol., 17, 482-487.

Wendhausen, R.; Fregonesi, A.; Moran, P. J. S.; Joekes, I.; Augusto, J. A. R.; Tonella, E. and Althoff, K. (2001), Continuous fermentation of sugar cane syrup using immobilized yeast cells. Journal of Bioscience and Bioengineering, 91, 48-52.

Received: January 21, 2002; Revised: March 25, 2002; Accepted: August 21, 2002. 